\title{
The First Annual Nelson Algren Memorial Poker Game · Burns Ellison
}

\author{
for John Clellon Holmes
}

\begin{abstract}
Yet why does the light down the dealer's slot Sift soft as light in a troubled dream?

( $A$ dream, they say, of a golden arm

That belonged to the dealer we called Machine.)
\end{abstract}

ON MAY 10, 1981, a friend called to tell me that Nelson Algren had died the previous day of a heart attack at his home in Sag Harbor, New York. He was found by a guest arriving for a party to celebrate Algren's induction on May 20th into the America Academy and Institute of Arts and Letters. It was on a Sunday morning that I got the call. On Mother's Day. And I felt as though I had just lost a father.

I grew up in a small town in Nebraska, where I read books voraciously. Starting with Jack London and Ernest Thompson Seton, I had worked my way up to more sophisticated stuff by the time I was in high school. Dashiell Hammett and Raymond Chandler. Detective novels with plenty of terse, clipped dialogue, violence, and raw - or what I thought was rawsex. Then there was W. R. Burnett, and James M. Cain and Horace McCoy, and Willard Motley and his book Knock on Any Door. One day I came across a book at the library called The Man with the Golden Arm. I read the jacket: "A story of the lost and the damned in a great American city." The book was peopled with gamblers and thieves, strippers, prostitutes, junkies and dope peddlers. It sounded promising. I took the book home, being careful not to leave it lying about. Strippers and prostitutes - no telling what my mother or father might stumble upon should either of them glance through it. But the book wasn't what I had expected. Frankie Machine was a far cry from Sam Spade and Phillip Marlowe; he was no Nick Romano, and he was certainly no Roy "Mad Dog" Earle. As for the sex stuff, there was nothing in it to match $I$, the Jury, or The Amboy Dukes. Not knowing what to make of it, I took the book back to the library without finishing it. 
On return trips to the library, I kept coming across the book. Apparently nobody else in Columbus, Nebraska knew what to make of it either. Somehow drawn to it, I kept checking it out, and somewhere along the way I read it. Then read it again. And again. The book wouldn't let me go. I was haunted by it.

Later, I read Never Come Morning. When I came to where Bruno "Lefty" Bicek seduces his girl friend Steff, then lets his pals take their turns with her, I felt almost physically sick. For I had been made to care so much about Steffi and how she was betrayed. And somehow too I found myself caring about her betrayer.

At the University of Nebraska, I majored in English, and took a course in creative writing - after all, I was going to be a creative writer. One day I went in to see my teacher about a story I had given him. "Well, I see you've been reading your Hemingway," he said. He was right, of course, and he would have been equally right had he said, "Well, I see you've been reading your Algren."

Ernest Hemingway was accepted by my teachers. They might not like him, but they couldn't deny him his place as one of the giants of American literature. On the other hand, Nelson Algren's name never came up. It didn't seem that he was academically accepted on any terms.

In my senior year I took a poetry course from Karl Shapiro, a Pulitzer prize winning poet. The University was proud to have him on its staff, and no poet, I was proud to be in his class. My mother and father were pleased about that too. They were supportive of my literary ambitions, but they felt there were proper ways one went about achieving them. My mother wanted me to be a writer by way of being a teacher, and my father by way of being a reporter, or going into show business. I had read Ben Hecht's $A$ Child of the Century, and his accounts of his years working on the Chicago News Bureau with Charles MacArthur. Hemingway had served his literary apprenticeship working on newspapers, and so I decided I would too.

In the spring of 1958 I worked as head waiter at the Elks' Club in Lincoln, Nebraska. With the tips I was making and what I could win in poker games with fraternity guys and football players playing on scholarship money, I made plans to go to Chicago. I had my degree, but I still wrote short stories and inflicted them on Karl Shapiro, who was generous with his time and kind with his criticisms. Knowing that he had once been 
the editor of Poetry, in Chicago, I told him that I was going there to be a reporter. He asked if I knew anybody in Chicago, and gave me the name of a Famous Syndicated Chicago Columnist, with a letter of introduction. Thanking him, I asked - almost as an afterthought - had he ever heard of a Chicago writer by the name of Nelson Algren. Yes, he had, in fact he knew him. And liked him, and thought highly of his work. He told me that when Dylan Thomas came to Chicago on one of his tours of the United States, he had been asked to show him the city; but instead he had turned him over to Algren, feeling he was the one to handle such an assignment. Thus, when I left Karl Shapiro's office that day, I not only had a letter of introduction to the Famous Syndicated Chicago Columnist, but one to Nelson Algren as well.

In Chicago, I stayed with a college friend on State Street, on the near northside. Chicago . . . Chicago was for me the magic city. It was the first big city I had ever lived in, and I was entranced, mesmerized, spellbound. I have lived in other cities since, but no city since has held me so much in its thrall. Sin and romance and adventure beckoned. Big city women, bars, jazz clubs, strip joints, slices of life on all sides. This was the "neon wilderness," with its thousand tales to tell, and I had only to learn them.

I still wanted to be a reporter, but much more than that, what I really wanted to be was Nelson Algren's private secretary. In that way I would serve my literary apprenticeship. Hadn't Samuel Beckett once been a secretary to James Joyce? Why not, then, me to Nelson Algren? Surely he had need of a secretary, perhaps he even had a staff. It would just be a question of whether there were any openings, and what kind of impression I made on him. He must have people working for him, I reasoned. After all, he was a successful writer, he had won the National Book Award, and two of his books had been made into Hollywood movies, one directed by Otto Preminger, starring Frank Sinatra.

I tried to get in touch with him, but his phone number was unlisted. I called Poetry, but nobody there could help me. Then I called the Famous Syndicated Chicago Columnist, and he agreed to see me. I went to his office and gave him my letter of introduction from Karl Shapiro. We had a pleasant visit and, when I told him I wanted to be a reporter, he gave me the names of a couple of editors. Then I asked him about Nelson Algren, if he knew how I could find him. He didn't know, but he gave me the name 
of a reporter who might. But why did I want to meet Nelson Algren? "He can't help you. He doesn't have any money. He only lives from one book to the next. Nelson's a nice guy," he said, "but he's mentally disturbed. There's nothing he could do for you unless you want him to teach you how to play poker."

That night I called the reporter and he gave me Nelson Algren's unlisted number. Then, heart in my throat, first bracing myself with a drink, I dialed the number, and suddenly I was actually talking to him. I don't know what I said-it was all I could do to catch my breath and make sounds. But he said he would see me. The following week. On the corner of Damen and Division, at eight o'clock in the evening. In the ensuing days I was in a state of revery, I was euphoric. Like the woman who'd once written him from Wheaton College, I felt I was on the threshold of my literary career. Meanwhile, I filled out job applications with the Chicago Daily News, the Chicago Tribune, and the Chicago News Bureau. Just in case. Not wanting to pin all my hopes on the private secretary position.

During that time I heard about a book of his called Chicago: City on the Make. I searched the bookstores for it, but nobody had it. I didn't understand: a book by one of Chicago's own, and it was nowhere to be found. Finally, I learned that it had been removed from the shelves. By order of the City Fathers. The book described as a "prose-poem to the city" was banned in that same city. Later, in a scuzzy hole-in-the-wall North Clark Street second-hand bookstore, I stumbled upon one copy of it, stuck away in the back shelves.

And what of my night with Nelson Algren - in that long ago spring of 1958? It was a raw rainy night when I set out to meet him. I went early, and already fortified by a couple of stiff drinks, got to Damen and Division with enough time to slip into a bar and have another. Sitting there, I rehearsed myself for what books and writers I'd be ready to talk about. Not wanting to have conversational lapses, painful, awkward silences. Then I staked myself out on the corner and waited. On pins and needles - on tenterhooks.

Then he appeared. He looked older and heavier, less lean and saturnine than his picture on the jacket of $A W$ alk on the Wild Side. But I recognized him at once.

"Mr. Algren," I said. He mumbled something in reply. Then we 
walked down the dark-lit street, ducking our heads in the wind and rain, the neons glowy and misted-over, the night Chicago raw. He walked at what seemed a peculiar gait, for I found myself either walking too fast or struggling to keep up. He said something, and then I was ahead of him or had fallen behind before I could reply. We got on a bus, got off, switched to another. We stopped in a bar, and he bought us drinks, then we went somewhere else and he ordered a pizza. Then another bar, this one noisy and crowded. I sat with my back to a circular stairway. "Jesus, look at the hide!" he exclaimed. I turned in time to see a woman's tawny long legs in a tight-fitting golden slit skirt ascend the spiral steps. I was shocked. Had he, a Man of Letters, said what I thought he said? This while I was trying to talk to him about books?

The night was a disaster. I was the Nebraska hick, the square straight from Squaresville, U.S.A. I had straw in my ears and cow shit on my shoes. Knowing the evening was going badly, I tried desperately to salvage it. I presented him with my ace in the hole - the letter of introduction. "Oh yeah, this is the first time I ever got one of these," he observed, giving it a bemused once-over.

The spring of 1958. That was the year a nineteen-year-old bandy-legged dropout named Charles Starkweather went on a murderous rampage in Lincoln, Nebraska, killing eleven people before he was tracked down and captured in Wyoming. Posses went on block-to-block searches through Lincoln for him and his fourteen-year-old girl friend, Caril Fugate. My father called me up and told me to stay at my fraternity house until the pair was captured. I stayed where I was, in the basement room next to the furnace, my landlady not wanting me to leave. Learning that I had just come from Lincoln, Nebraska, Algren wanted to talk about Charlie Starkweather. I turned the conversation to Camus and Sartre. He brought it back to Starkweather. I mentioned the movie version of The Man with the Golden Arm. "Oh, don't talk to me about that," he said. I went back to Camus and Sartre. Camus and Sartre! Now how was I to know he probably had no desire whatsoever to talk about French writers? I didn't know about him and Simone de Beauvoir, and wouldn't find out until several years later when I read The Mandarins.

So the evening went. I talked about Thomas Wolfe and Jack Kerouac, he talked about the Carmen Basilio-Sugar Ray Robinson fight. It had been a brutal one, and he didn't think either of them would ever again be 
the same fighter. On our way to another bar he stopped to talk to a woman in a doorway. He told her I was from Nebraska. She looked at me dubiously, and we kept walking. "You know," he said, "I think she must have thought you were a cop." I told him I wanted to be a writer, and that I wanted to learn the city. He suggested I get a job on the police force, that was a good way to learn the city. Or I could start up a literary magazine and call it "Chicago." Screwing up my nerve, I asked whether he might need a private secretary. He said something about Sartre having had one, but he himself didn't need anybody at the moment.

And I never even thought to ask him about playing poker. That was the only thing that might have saved the evening. I went back to where I was staying, devastated. It had all gone horribly, and I was years recovering from it. At least, though, it had been left that we might get together again.

A day or two later I got a call from the Chicago News Bureau. They had an opening for a cub reporter-copy boy - and I took it. I don't know how I got the job. Maybe somebody put in a word for me. Maybe the Famous Syndicated Chicago Columnist. But I preferred to think it was Nelson Algren. Bringing his influence to bear. "Here's a guy who strikes me as a real comer," he might have told the editor. "Of course I may be stealing him away from you if I decide I need a private secretary."

In the meantime Chicago remained for me my magic city. Sin still beckoned, and romance, and adventure. I went along with veteran reporters to the police courts. I sold apples and soda pop on weekends at Comiskey Park - saw my baseball idol Ted Williams go hitless, four times at bat. I listened to the soapbox orators in Bughouse Square, stepped over drunks on West Madison, got hustled for drinks by strippers on North Clark, played 26 dice with B-girls on Division. I remember rolling the dice with one woman in particular. Blowzy and overripe, she had a large wart on her nose. And a neckline that plunged so low that when she leaned across the green felt table I thought her large white breasts would come toppling out. When she asked me if I'd like to go upstairs, I inquired what for. She said she would take me around the world. For $\$ 15$. But I wasn't ready to go that far. I wasn't even ready to go upstairs. I stammered something and left. I got flim-flammed by a carny in a three card double-your-bet-double-your-money game in which I was assured I couldn't lose. I dated a girl with raven black hair of French descent. We 
spent evenings seated in front of her fireplace drinking red wine. Reputedly she had loose morals; she didn't loosen them for me. I dated a girl who had dated Hugh Hefner. She was blonde and Polish, and for a brief time I thought I was in love with her. She looked just like how I imagined the real Molly-O in The Man with the Golden Arm would have looked, as opposed to Kim Novak.

And the streets: Division, State, North Clark, West Madison, Dearborn - I walked them all ... I was walking the wild side. I explored the Loop, and endlessly rode the Els. And the curious thing was, bartenders, cabbies and elevator operators, cops and reporters, strippers, B-girls and barflies, winos, carnies and ball park concessionaires - they all talked like characters from out of a Nelson Algren story. Or, at the very least, as if they had been reading the jackets on his books. I tried to hire out with a day labor crew. Seven o'clock A.M. I stood in a line of men nearly a block long waiting to be interviewed by the hiring boss. Bottles of cheap booze were passed around, men were already drunk; fights broke out.

"You don't wanta work down here," the hiring boss said, glancing up from the application form in which I'd noted I was a college graduate. "This is the street of the dispossessed."

I called and talked to Nelson Algren again, twice. The first time he said he was about to leave town, the second time I was about to. I was taking a leave of absence from the News Bureau to go to the World's Fair in Brussels - by way of Las Vegas, Nevada. I never got to the World's Fair, though I did Las Vegas, but that's another story. I told him my plans, thinking he might suggest we get together. Unfortunately, he was tied up, but he had a couple of suggestions for me if I was at loose ends. He said if I went to the corner of 16th and Kedzie and asked for a girl named Candy, she would show me a good time. But he cautioned me not to come on too strong. I might make her think I was a cop and scare her off. His other suggestion was that I take in the Lincoln Park Zoo; they had a marvelous animal house. He paused. Thinking it over, he said I might be better advised to take in the zoo than look for Candy. As it turned out, I did neither. When I should have done both.

Leaving Chicago, I had one consolation. I knew-I was inbued with all the belief in the world - that one day I would write something that would make Nelson Algren sit up and take notice. No sir, I wasn't going to need a letter of introduction the next time we met. 
In the early 1960s, I went back and forth between working as a houseparent in a home for emotionally disturbed children near San Francisco and attending the University of Iowa Writers' Workshop in Iowa City. I still wrote short stories and by then I had an agent. The agent never got any of my stories published, but she did get me better rejects. The Writers' Workshop never got any of my stories published either, but I was in school again, and my father felt better about that than when I was a swimming pool cocktail boy in Las Vegas, or writing keno tickets in Lake Tahoe.

One night in City Lights Bookstore in North Beach I heard that Nelson Algren was coming to town. He was giving a lecture at San Francisco State. A friend and I went to hear him. He didn't strike me as being much of a public speaker: his syntax was broken, and so was his train of thought. At one point he stopped and began fumbling through his notes on the podium. "I think, uh, somewhere along in here I was supposed to launch into an attack on Leslie Fiedler. Yeah, yeah, uh, here we are . .."

At the end of the lecture, I pushed and elbowed my way up to where he was fielding questions and signing autographs. Somebody asked him what he planned to do while he was in San Francisco, and he said he hoped to get out to the track. I got up close enough to speak to him, but then when I had my chance, I lost my nerve - I froze. I went back to where my friend was waiting for me. "See that big burly guy with the balding head you kept pushing out of the way?" he asked with a grin. "Listen, you're lucky he didn't take a punch at you. That's Ken Kesey."

But I didn't care about Ken Kesey. Five years had passed, and I still hadn't recovered from that night in Chicago. Five years, and I still hadn't done anything to make him sit up and take notice.

I attended the Iowa Writers' Workshop on a sometime basis, a year here, a semester there. Not aiming for a degree; no M.A. or M.F.A. or $\mathrm{Ph} . \mathrm{D}$. for me. Those who wrote, wrote, and those who didn't, taught. Let the others hedge their bets and get degrees, but not me. I was there to write and to be in the workshops taught by the likes of Vance Bourjaily, Philip Roth, Richard Yates, John Clellon Holmes, R. V. Cassill, Tom Filer, Adrian Mitchell, and David Pryce-Jones.

Then there were the poker games. My first semester in Iowa City, I joined the Moose Club because that was where the games took place. There I met Gilroy. In his mid-twenties and already cueball hairless, Gil- 
roy sold shoes and, along with playing at the Moose Club, hosted a weekly poker game in his basement. His wife collected three dollars from each player and provided sandwiches. One year, I arrived on a Greyhound bus to Iowa City in time to pick up my fellowship check from the Workshop and lose it that night in Gilroy's weekly game. The next morning, I called the place where I'd worked with the kids in California - the place I'd just left - to see if I could go back, then borrowed enough money to get back on the bus that afternoon. I worked there for another year and returned to Iowa City the next fall. Then, during the spring semester of 1965, I decided I'd stretched things out far enough. Instead of being an expatriate on the Left Bank of Paris, I'd had Iowa City. It had been a special place for me, but I couldn't keep going back to it forever.

In the fall of 1965, I was in California when I got a letter from Pablo, in Iowa City. Pablo wrote to tell me that Nelson Algren was there that year, as a guest lecturer in the Workshop. He had been reluctant to come to Iowa City, but the Workshop kept upping the ante until he couldn't afford to turn the offer down. He had recently married an off-Broadway actress, and I gathered from Pablo's letter that Iowa City was no Left Bank as far as either of them was concerned.

Algren had arrived some weeks after the semester started, which didn't make the students happy who had signed up for his workshop section. Nor were they happy about his choosing to mimeograph stories for his section by people like Terry Southern, Joseph Heller, and James Leo Herlihy, instead of theirs. Pablo didn't think the Workshop and the English Department were too happy with him either: asked to speak at some large University banquet, Algren had told this incomprehensible story that had to do with Nijinsky hitting Diaghilev in the face with a nine-pound mackerel. Pablo also informed me that Algren was playing in the poker games, and Iowa City, he let me know, had never seen such games. What's more, and this was the capper, Pablo had given him one of my stories, one of my "rejects" to read, and Algren had had it mimeographed and used it in one of his workshop sections. Nelson Algren had mimeographed one of $m y$ "rejects"! And I wasn't even there! I was in California. But not for long. How could I not go back to Iowa City? One more time. And in February of 1966, in time for the spring semester, I did. 
As once before, my arrival in Iowa City coincided with the weekly game at Gilroy's. Pablo couldn't play, having lost too much the week before, so I went to the game alone. First, though, I dined out, treating myself to a steak dinner. And several screwdrivers. To fortify myself. There was, after all, not only the prospect of a high stakes game, but this time he would be in it.

It was close to midnight when I got to Gilroy's. I went down into the basement where the game was underway. It was a full table, and a few guys stood around watching. Algren sat there in an undershirt smoking a cigar, drinking from a thermos of coffee laced with brandy. He glanced up only briefly when I walked in. If he remembered me, he didn't show it. I waited until a seat opened up. I was introduced around the table. Algren nodded. Still not a flicker of recognition.

I bought in for my chips, and the cards were dealt. Pablo had said Iowa City had never seen such poker games. That was unquestionably true, and Algren's presence was unmistakably why. Twenty dollar, and forty and fifty dollar bets were being made right and left. Calls and raises, more raises, with him playing in nearly every hand. The night and the game wore on. I sat there, immersed in the glow of the overhead light, and in the warm boozy, blurry glow of all the drinks I'd had. And for me, the game began to take on an aspect of unreality. A few years before, I had written a poker story set in a California cardclub. I called it "The Live One." The "live one" of the story brought action to the game, brought life. He was loud and crude and boisterous, bought everybody rounds of drinks and kept up a running patter, cackling gleefully at his own corny jokes. He bluffed and got caught, called and raised on hands he had no business even playing. In the night's big pot, in a game of lowball, where best hand is low hand, he tried to win it with four kings and lost. Losing everything he had, to the tune of $\$ 1200$, he laughed and walked away, the only winner, the only "live one" in the game.

And though I had never seen him play in a poker game, the "live one" in my story had been Nelson Algren. And now, here, in Gilroy's basement, Algren was indeed that "live one." He too lost pot after pot, called and raised on hands he had no business playing, bluffed outrageously and was caught, and all the while kept up his running patter, cackling gleefully at his own corny jokes. And in games of seven card stud lowball, he stayed and called and raised on hands where it was clear to everybody that the 
only way he could win was if high hand took the pot.

"You gotta be kidding," he exclaimed, arching his brow in disbelief, glancing around the table. "You say the game is lowball! No, don't tell me that." As he flipped over the kings he had in the hole. To go with those he had showing.

Nor did it stop there. It didn't stop until six o'clock the following night when the game broke up and Algren walked away from it, having lost $\$ 1200$. While I, who had never dared to ask him for his autograph on that rainy night in Chicago, walked away, my billfold bulging with his autographed checks.

The weekly game and the weekly workshop section. Algren would arrive in class with stacks of magazines, newspapers and book review sections that he placed on his desk for all those who wanted to help themselves. The classes often started late and ended early. He obviously wasn't comfortable presiding over a class, discussing Literature and the Art of Fiction. He didn't believe you could teach anybody how to write; he himself was only a "journalist," or so he said, and maybe, just maybe, he could help somebody be that. The only times he seemed to feel at ease were when he dispensed with talking about the Art of Fiction and told his stories, his anecdotes about hookers and pimps, junkies and barflies, bookies, gamblers and racetrack touts, misfits and rejects - all of them Life's Losers. One time he read aloud his story "How the Devil Came Down Division Street," and then he warmed to where he was.

Only then he wasn't "there," not in a classroom in Iowa City. Just then he was with Roman Orlov, in the Polonia Bar, on Division Street, Chicago. Sometimes, at the end of a class, Algren and some of us would stop at one of the Iowa City bars. He would invariably buy the drinks, then go on with his stories and anecdotes. But as the weeks went by, classroom attendance fell off. Students stopped coming or switched to other workshop sections. They had enjoyed hearing his stories about Life's Losers, but only up to a point; after all, they were Life's Winners. What did any of them have in common with Roman Orlov, the biggest drunk on Division Street? 
The weekly game and the weekly workshop section. I didn't see much of him other than on those occasions. There was the time, though, when I decided I would introduce Nelson Algren to the Iowa City underbelly. I asked my friend Robert if he and his wife Beryl would care to join in such an outing. Robert was a poet in the Workshop and taught a course in freshman English; Beryl was a graduate student in anthropology. On the evening in question, Robert had to prepare for a morning class and said he could only make a token appearance. Beryl, however, had the evening clear, and could provide the car. We took Nelson to the Sportsman's Lounge, outside Iowa City. The downstairs part of the place was called the Dugout. A black go-go girl named Betty danced in the Dugout. Having met her at a few Iowa City parties, I asked her if she would reserve seats for us. We entered a large smoke-filled cellar. In the center of the dance floor was an elevated cage. The Dugout was jammed with beefy, ruddy Iowa farmers, truckers, construction workers, traveling salesmen. We found our table and ordered drinks. When the waitress delivered them I belted mine down. I was all right in the poker games, but what about now? Would it happen again? Would this prove to be another frasco like that night in Chicago? What should I say to get the ball rolling? Talk about Camus and Sartre? Fortunately, Beryl was on hand. Learning that she was an anthropologist and that she had been to South America, Nelson mentioned Peter Matthiessen's book At Play in the Fields of the Lord. Then they talked about Claude Levi-Strauss and his classic anthropological work Triste Tropique. Nelson wondered if sometime she could introduce him to Claude Levi-Strauss. Beryl gave me a hurried glance-was this guy serious? - but then assured him that of course she could, flashing him her winning, charming smile.

What was this, anyway? He balked at sitting in a bar with me and talking about books and writers, and here he was going on and on about Peter Matthiessen and Claude Levi-Strauss. But then I wasn't blue-eyed and blonde with long flowing hair, and I guess I didn't have a winning, charming smile. I ordered another round of drinks. Beryl's husband Robert arrived, and we got onto the subject of movies, and now Nelson was telling movie star stories about Lauren Bacall and Jason Robards, Rip Torn and Geraldine Page, Tony Curtis and Shelley Winters. The drinks kept coming, and whether we talked about Levi-Strauss or Lauren Bacall, it didn't matter. Things were going splendidly, and I was delighted. This 
wasn't going to be a repeat of that night in Chicago, after all.

Then Betty appeared. Tall and long-limbed, lithe and glistening ebony, she climbed up into the elevated cage and began to dance. Gyrating, twisting and turning, bumping and grinding, she brought the crowd to a frenzy. Seeing me in the audience, she invited me to climb up and join her. Now I had no more business dancing with her than I would have with Cyd Charisse. But that didn't stop me. I was showing Nelson Algren the Iowa City underbelly. So on this night I danced. Then, not one to be outdone, Nelson climbed up into the cage, and he too danced. The farmers and truckers, construction workers and salesmen, whooped and hollered and roared their approval. Not suspecting for a moment that they had a Man of Letters up there. Probably they thought he was just another dirty old man. Probably they were right.

Yes, the evening was a rousing success, beyond my wildest dreams. That is, it was, and then, suddenly, it wasn't. Because suddenly I knew - I was in trouble. All those vodka gimlets. I'd had too many, and I had been drinking them down much too fast. The table careened, the faces around me reeled. I got to the men's room, but only in the nick of time.

Then needed help to get out. And out of the place and into Beryl's car. From then on, my only recollection is of being driven home through the night with my head hanging out from the rear window, in horrible distress. While from the front seat Nelson kept up a running patter about how he had called up Jason and Lauren and Shelley, and how they were all waiting back at his house, wanting to meet me and make a night of it. “. . . And Tony said he didn't know if he could make it this time, but when I talked to Bob Mitchum he said he was a definite. But Burns, are you sure you're okay? You know, I think maybe you better get a cup of coffee first. I don't know, Burns, you don't sound so good." Cackling gleefully all the while.

Nelson didn't have an office on campus so I met with him a few times for story conferences at his home. "Hello, Burns, come in. How are you? Sit down. What would you like to drink?" Nelson's wife Betty would briefly appear, going from one room to another, or leaving as I entered. "Here, you read this guy's book?" he'd ask, thrusting a reviewer's copy on me. "It's not bad, I just finished it. Take it with you and tell me what you think of it." Then, after fixing drinks, he's sit down and we'd go over the 
previous week's game, who won the big pots, who made the big plays.

Or I met him for story conferences in the University of Iowa Student Union, which was a hotbed of gambling activity, whether it was bridge or rummy, pool, billiards, or ping-pong. A number of those who hung out there took part in the poker games. When Nelson showed up, people invariably stopped by his table, and in no time he'd be talking not only about the previous week's game, but poker games and big pots won and lost over the years. On both occasions, so much for story conferences.

But then at three o'clock in the morning, in the game at Gilroy's, Nelson would suddenly say, pausing as he dealt the cards: "You know, Burns, I been thinking about it, and I'll tell you what the problem is with your story, why it doesn't work."

"Nelson, Nelson," Lepp would intone, "deal the cards, Nelson."

Lepp was grubby and puffy-faced, chronically in need of a shave. He always wore the same crumpled raincoat to every game, and the raincoat and the clothes he wore under it always looked like they had been slept in. Dry and laconic, Lepp looked like the biggest loser in the game when actually he was the game's biggest winner. But then he had to be. He supported a wife and five or six children on what he won.

Three o'clock in the morning. Gilroy's basement. “ . . . Burns, that story of yours, I think you gotta do something more with the ending. You gotta punch it up. You got this guy who's glued to the TV set. There's nothing happening in his marriage, so all he and the wife do is watch TV and cut each other up. But then when the guy cracks, I think you gotta have him doing something with the TV. Yeah, the TV's gotta figure in it. Like what I once read in the papers about this guy who got so mad at his TV that he took out his gun and shot it. Yeah, something like that."

"Nelson, Nelson," Lepp would intone, "are you going to call?"

"Oh," Nelson would say, arching his brow, "was I holding up the game? I'll call and raise twenty." The game is seven card stud lowball. He hasn't looked at his hole cards and his first card up is a king. And he calls the bet and raises $\$ 20$. Against Lepp, Gilroy, Pablo, Thede, the Cincinnati Kid, and me. All of us just sitting there, like sharks, waiting to beat him out of his money. 
The weekly game and the weekly workshop section. How much more vividly I remember the former. And the players. There was Thede, or the "Bear," as Nelson called him. In his early twenties, Thede could have passed for twice that age. A poet who venerated Yeats, he came to the game wearing a three-piece Irish green suit, and bearing a brief case which always contained a bottle of good Irish whiskey. He affected a cane, wore thick-rimmed glasses, and given his bear-like proportions, short-cropped hair and handlebar mustache, looked a good deal like the Rough Rider himself, Teddy Roosevelt.

"Drinks and camaraderie," Thede would say as he raked in a pot and hoisted his bottle. Thede built the pots and bulled them. Was a great one for intimidation. "What have you got left there?" he'd ask, eyeing what chips a fellow still had. "I'm afraid I'll have to tap you. Put you all in." Then shove out his own stack. And of course when he did, Nelson had to call him. Thede was a tough and canny player, but one night he got tapped out himself. Whereupon he turned to the Cincinnati Kid, the night's big winner, and inquired: "I say, could you pass over a couple hundred?" Now everybody at the table knew that only the week before Thede had staked the Kid to two hundred when he got tapped out. So what did the Kid say now?

"Sorry, Thede, can't do it." Terse, clipped, noncommittal-like Steve McQueen. "Don't believe in playing against my own money." Thede looked at him. "Well, fair is fair," he said, lurching to his feet, cane in one hand, bottle in the other. "Ah yes, the drinks and camaraderie." And went off into the night.

When the Cincinnati Kid wasn't playing Steve McQueen playing the Cincinnati Kid, he was playing Paul Newman playing the Hustler. Sober, he was a deadly pool player and a good poker player. He prepared for the weekly game like a fighter before entering the ring. No sex the night before, no booze. A good night's sleep. His choice of attire was important too. Sometimes he wore his Chief Petty Officer's navy blue sweater, levis, and engineer boots, with his duck's ass freshly trimmed. Other times he wore his gangster outfit, black on black, with silk white tie. And brought to the game his "moll." His "moll" sat at his elbow, and never spoke unless spoken to first. She sat through the all-night hours, fetching him Pepsi Colas on command. When he stuck to Pepsis, the Kid was hard to beat; but sooner or later, he'd hit the hard stuff, and when he did, he always lost. 
"You know what the problem with that guy is," Nelson would say. "There's nobody there. You know what I mean? I mean how can you talk to the guy? There's nobody there. He's a ghost."

Later, after we had all left Iowa City, Nelson was incensed when the Cincinnati Kid, having gone to Alaska, used him for a reference. For a job on the Fairbanks police force. And what incensed him, stuck in his craw, was that anybod $y$ would have used him for a reference to get a job as a cop. "What position was Mr. holding when you knew him?" the police questionnaire asked Mr. Algren. "Two seats to the left of Gilroy, one to the right of Lepp," was Mr. Algren's reply. "Would you trust this man with your money?" "No!" "Would you trust this man with your wife?" "No!" "In your opinion is this individual qualified to be a member of a law enforcement agency?" "Yes!" Needless to say, the Kid never got the job. Instead, he wound up dealing a house game in Anchorage.

Three o'clock in the morning story conferences. At Gilroy's.

"Burns, I'll tell you what your problem is. Your problem is, you take too long to get to the point."

"Nelson, Nelson, the bet's on you ...."

I thrust my "rejects" on him, and he savaged them, bluepenciled them to pieces in an illegible scrawl that to this day I can't decipher. One of my rejects was about an alcoholic night club comedian who takes up yoga. With that one he not only bluepenciled it, he sat down at his typewriter and rewrote it. I came to feel that he treated my literary rejects in much the same way he treated the human rejects of his stories. Which is to say, he made me feel that they mattered. And the day Kurt Vonnegut attacked one of my rejects in a joint workshop meeting and Nelson Algren defended it was my shining hour in Iowa City.

That semester I stayed with Pablo in his farmhouse ten miles outside of town. I lived in the attic, the beams and rafters covered with owl shit. Outside my attic window were dense woods and a ravine leading down to a reservoir where in the spring I fished for bullheads. On Mondays, Pablo and I drove into Iowa City for the workshop section; and on Thursdays, we drove into town for the game.

Playwright and intellectual, Anaïs Nin his godmother, Pablo wasn't 
Spanish, but he spoke the language fluently. He wasn't of Latin descent, but he had spent some years with the American Embassy in Panama and Guatemala, beach-bummed in Mexico, and had an affinity for Latin cultures and Latin women. Pablo read all the books on how to play poker and win. He analyzed the hands, played percentages, and watched the cards and players with the same diligence and acumen he would have brought to doing a critical re-evaluation of Pushkin. Yet somehow Pablo's card - the one needed to catch a wheel, make his flush or straight, fill his full house always seemed to fall just before or after him. But if the cards weren't running well for him that year, cars were. Pablo loved to invest in old clunkers and make them run. He had a gift for that, a knack. If the clunker broke down, he always knew what to do to make it start. But God help me when I drove any of his clunkers. Tires blew out, fan belts broke, and clouds of steam billowed up from under the hood.

When Pablo and I drove in for the game, we often picked Nelson up. If Pablo couldn't play, I borrowed his car and picked Nelson up. Knowing each time that I was living life on the edge. Because if Pablo's clunker gave me problems, I couldn't turn the wheel over to Nelson. I drove badly, he drove not at all. I knew almost nothing about what makes a car run, he knew less than that. And if I got lost, he was no help there either. When Nelson couldn't get chauffeured to the game, he took a cab or walked. There was the night when he hadn't shown up and a raging Iowa blizzard was underway. We called his home; his wife said he had left some time ago. On foot. Everybody got understandably anxious when they heard that; after all, what would the game have been without him?

He too knew he was taking his chances on such nights.

"Yeah, I saw myself being found frozen to death in a snowdrift, for getting lost and walking around in circles trying to find my way to Gilroy's poker game. In a snowstorm. In Iowa City! Yeah, I thought to myself, what an awful, what a horrible way to go!"

And we would ask ourselves - how had he survived for as long as he had? How had he survived those years in the '30s, hoboing and riding the rails in Texas and Louisiana. All those years on the "wild side." He had come through all that, but how?

And did he ever win in any of those poker games? Oh, a few times, but mostly there were all the times that he lost. "You know," he would say as he shuffled the cards and asked for a cut, "my wife says I'm a compulsive 
loser. She thinks I ought to see a shrink. She says I got a problem. Now is that what you think?"

"Deal, Nelson, deal," Lepp would intone, while Nelson waited for an answer to that one. We thought the game that year probably cost him half his salary and a marriage besides. Once I tried to talk to him about his play. I told him he had to protect himself, change his style, that he didn't have a chance against those "sharks," that they were just waiting to carve him up. That was a mistake on my part, one of three mistakes I would make with him. He thanked me for my advice, but there was a distinct edge to his voice.

"Nelson, you've got a 'tell," "Lepp told him one night as he raked in the pot after calling Nelson's bluff. Nelson didn't know whether to believe him or not. Still, Lepp must have known something. Maybe it was in the twitch of his thumbs. Henceforth when he bet, he shoved his chips out, then quickly slipped his hands under the table. Thumbs concealed or not, he kept right on losing.

There was one player in the game he could beat. John the Barber. Who himself couldn't beat anybody. John the Barber was a sad woebegone guy who never came in with enough money, always played short, and always lost. One night he arrived just in time to be in the hand. He called the bet; somebody raised; somebody else re-raised - then another raise. John the Barber didn't even have a chance to sit down and take his coat off, and he'd lost the hand and everything he came in with.

After losing, John the Barber would stick around and watch. He took a particular interest in Nelson's play. He'd edge his chair up to Nelson's, and, sitting there, craning his neck over Nelson's shoulder, discuss with him after a hand what he should have done. If there wasn't an extra chair, he'd be on the edge of Nelson's chair, scrunched in so close he was practically in his lap, nose to nose with him as Nelson squeezed out that last card in the hole. Had he had more of a sense of humor, John the Barber might have passed for Frankie Machine's dog-stealing sidekick, Sparrow.

Sometimes Nelson gave him a five spot to go out for a bottle. Or maybe a ten spot so he could get back in the game. That way Nelson had his chair to himself. But then John would lose and be right beside him again. In return for the times that Nelson beat him for money he didn't have, John the Barber gave Nelson his markers, non-negotiable. He passed out his markers to everybody else too. Then came a night when he didn't show 
up, and next we heard John the Barber was in jail for passing bad checks. If Nelson left the game with anything that year, it was probably with some of John the Barber's markers, non-negotiable. I don't think Nelson had much else to show for his year in Iowa City. So is it any wonder he had so little use for Writers' Workshops?

Maybe it was as with one of his characters, he "couldn't bear being a winner." As Nelson saw it, being a writer in America, one had to be a loser. Maybe that extended to poker games too.

At least he didn't leave Iowa City with any of Micky Hagen's markers. The ones he had, I wound up with. Next to John the Barber, Micky had more markers out than anybody else in the game. But at least Micky had a teaching job and was regarded as a promising young poet. I took his markers telling myself that someday they would be good. Two weeks later, though, Micky had split. The word was, he'd quit his job, packed his bags, and gone to Fresno. Fresno, California. Though nobody really knew for sure. I've tried Fresno information over the years, but have never been able to get a listing.

I don't think Nelson thought the less of either John the Barber or Micky Hagen. They had simply gotten in too deep, that was all. That didn't make them bad guys, merely fallible. But he felt differently about the guy he called Baby Filbertson. But then Nelson felt differently about anybody not making good on a gambling debt when he was clearly able to.

Baby Filbertson was fat and had a face like a "psychotic infant," as Nelson ungenerously phrased it. An acknowledged genius as a bridge player, he was petulant and complaining at poker, a bad loser and a worse winner. One night, he lost heavily and left the game owing money, much of it to Nelson. A week later he was back in the game and winning. Nelson was losing and asked Baby Filbertson if he would settle up with him. Baby Filbertson said no, not now. When he went upstairs to use the john, Nelson went after him. The game went on. Suddenly we heard screams from Baby Filbertson. "Help! Help! Get this mad man away from me! He's trying to kill me!" Then we heard screams from Mrs. Gilroy, at that time very pregnant. Screaming for her husband to get these men out of her house before she called the police. Gilroy dashed upstairs. The game went on. As to what happened upstairs, apparently blows were exchanged, though no blood was drawn. A lamp got knocked over, I think Baby Filbertson went for it trying to defend himself. Or on reaching for 
the telephone. In any event, Nelson wound up with both, the lamp in one hand and the telephone receiver in the other.

"There I was, and I didn't know quite what to do," he later admitted. "See, I didn't know whether to hit him with the lamp or the telephone receiver. Or maybe I should drop the lamp and receiver and then hit him. But then I couldn't get an angle at him anyway. Because, you see, he's down on the floor with his hands over his head and his big ass up in the air yellin' I'm trying to kill him. And all I wanted from him is my money. And Gilroy's wife is upset and I feel badly about that, and I didn't know what to do. So finally I gave him a kick in the ass and went back downstairs."

That was when Professor Krebs announced he would have to drop out of the game, feeling there was no excuse for such behavior. More to the point, word of such goings-on might get back to the "department," and he "had his position to uphold."

Nelson loved that phrase, and went around using it for weeks. "I don't know, Burns. I may not be able to attend Dean Gilroy's next meeting. You see, I have my position to uphold. Besides, I'll have to check my holdings." Check his holdings. That was another phrase he latched onto. Finding himself in Iowa City, Iowa, in the heart of Squaresville, he played it like an old vaudevillian, stepping on his own punch lines, cackling and sputtering with laughter.

So where did I think I came off? A Nebraska boy, product of small town middleclass mid-America. And a frequenter of Writers' Workshops to boot.

As far as I know, Nelson never went into Kenny's, the local "bohemian" bar, and if he ever went to any of the Iowa City parties, they weren't the same ones I got invited to. As for his wife, the bride he brought to Iowa City, none of us knew her. I remember that she was a dark-haired, rather striking woman, that she was probably twenty years younger than Nelson, and that she wasn't terribly friendly. Formerly an off-Broadway actess, in Iowa City she taught a course in the speech department. That was part of the deal in Nelson's coming to teach in the Workshop.

The one evening I spent with her was on Nelson's birthday. Wanting to treat them to a dinner out, I got a date and borrowed a sport coat and we all went to one of the local steakhouses. After all, this was Nelson 
Algren's birthday. Nor did he stint himself on the occasion. He ordered rounds of martinis and the most expensive steak on the menu. "Yeah, and let me see your wine list. And afterwards we'll want something more, so stick around," he told the waitress. "And make sure you give my father here the check."

Six months later, when I saw him in Chicago, he was alone, his wife having returned to New York. He said they'd had an amicable parting, and that they still kept in touch. She had taken the cat and the car, but that was all right. The cat was sick all the time and he couldn't drive a car anyway.

Maybe one of the reasons that students dropped out of his class or switched to other sections was that Nelson was an anachronism. He came out of a tradition that went through Hemingway and Dreiser and Ring Lardner, back to Jack London and Stephen Crane, then back to Mark Twain. With him that tradition ended. He was unique, the last outlaw of American letters. Of course everybody is unique, but as he had pointed out, some people are uniquer than others.

In the 1960s, when John Dos Passos was writing for the National Review and trumpeting Barry Goldwater, when Jack Kerouac was beating the drums for William F. Buckley, and John Steinbeck was sending back glowing dispatches from Vietnam about what a terrific job Charlie Company was doing mopping up the Viet Cong, Nelson remained true to his outlaw colors.

He had once said "American literature is the woman in the courtroom who, finding herself undefended on a charge, asked, 'Isn't anybody on my side?" "In the spring of 1966, he might have said American literature is taking a stand against what the United States was doing in Vietnam. During his year in Iowa City, he got invited to lecture at various colleges and universities. Teaching in the Workshop put him on the campus lecture "circuit." "Going on the Ho Chi Minh Trail" was how he put it. He took with him a record of Ernest Hemingway readings and a record by Lord Buckley. Hemingway reciting "Saturday Night at the Whorehouse in Billings, Montana," Lord Buckley talking about the Nazz, and Nelson Algren denouncing our involvement in Vietnam - that was what his listeners got when he spoke on the subject of American literature.

For Vietnamese peasants took their place along with all those others 
with whom he so identified, and whose side he took. All those whose lives were lived within "a ring of fire."

"We are all members of one another," his defrocked priest in The Man with the Golden Arm had said when he took his turn in the police lineup.

"What had the holy-sounding fraud meant by that?" the captain with the charge-sheet had wondered. And I too had wondered when I was a sophomore in high school and first read the book. What was something like that doing in a cops and robbers story?

"We are all members of one another."

Or, to quote the lines from Walt Whitman that Nelson himself so often quoted:

"I feel I am of them-

I belong to those convicts and prostitutes myself,

And henceforth I will not deny them-

For how can I deny myself?

But if he was one of them, that didn't extend to lawyers and brokers and realtors, dentists and engineers. Or businessmen, professors, and Hollywood producers. He was not one of them, them he denied. "I may be in it, but I'm not of it," he had said, talking about middle-class America. Somebody has pointed out that his compassion stopped there. I think in some measure that was true. He had become convinced early along that he was being lied to, that the fix was in, the game rigged, and that one's only rightful place was with the duped, the conned, and the victimized. So that he had to lose in the weekly game at Gilroy's. After all, where would that have put him had he won?

There were only a few on hand for that year's final game. Pablo and the Cincinnati Kid had gone to Alaska, and Micky Hagen to Fresno. John the Barber was in jail. Professor Krebs wasn't there because he "had his position to uphold," and Baby Filbertson had gone back to playing bridge. Pablo had left his clunker of a stationwagon behind, and I drove it to the game, picking Nelson up on the way. Afterwards, at five o'clock in the morning, I drove him home. Both of us had lost, and we were both tired and hung over.

"Nelson, if I could ever do you a turn, I would," I said to him. 
"Why, thank you, Burns," he said in formal, almost courtly fashion. "I'll remember that." He said he would be spending the summer at the Cahokio Downs racetrack in Bellevue, Illinois. If I happened to be in the area, I should look him up. Then he got out of the car. Later that day, he and his wife left for Chicago, and I got on a bus to San Francisco.

In the fall of 1966, I spent a few days in Chicago. I stayed with Thede - Thede the "Bear," who was living in a cheap hotel off Howard Street. We shared his Murphy bed. Thede had come upon hard times. He was selling encyclopedias, but he hadn't made any sales for awhile, and he was weeks behind in the rent. The management carried him, but they were keeping a close eye. One day Thede decided to take the train to Rock Island to see old friends. Needing to borrow some money, he decided to give Nelson a call. But if he used the pay phone in the hotel lobby, he wouldn't have enough money left for bus fare to get to where Nelson lived. So he took the bus, taking his chances that Nelson would be home. First, however, he packed his toilet kit and a change of shorts in his boot box so that the management wouldn't think he was trying to skip out on what he owed them. Arriving at Nelson's apartment and finding he wasn't there, he sat down on the steps to wait. When Nelson showed up, he invited Thede in and broke open a bottle of Hudson's Bay Scotch. Thede explained the purpose of his visit.

"I'm sorry, Thede, but I don't have anything for you," Nelson told him. Well, that was how it went; Thede would just have to postpone his trip. He finished his drink and made ready to leave.

"Here," Nelson said, shoving a cigar box at him, "take what you need." The cigar box was full of bills and loose change. Thede took what he needed, then used Nelson's phone to call his friends to tell them he was on the way. Later, on the train to Rock Island, Thede dug into his boot box for his toilet kit before retiring to the club car and discovered what was left of the bottle of Hudson's Bay Scotch that Nelson had wrapped in his shorts.

While staying with Thede, I gave Nelson a call, and he invited us over for drinks. He had just acquired a remote control push-button channel changer for his TV, and he wanted to show it off. He brought out a pitcher of martinis and we watched "Laugh In." During commercials, or when somebody came on he didn't like, he switched channels or turned 
the TV off. Without even having to budge from his easy chair. He was very pleased about that. Then he told us what he had done to Fish. Fish Mike the Fish: he had played in some of Gilroy's games. In pre-med, or maybe it was pre-law, cocky and abrasive, Fish won heavily and lost heavily, playing with his father's money. At the end of the year, Nelson found himself stuck with one of Fish's markers.

"I told him I'd like for him to pay me the money he owed me. Fish was very contemptuous about it, and said he would when he got around to it. So I waited a few months, and when he didn't get around to it, you know what I did? I finked on him. Yeah, I finked on Fish," he said, chortling with laughter. "I called up Fish's old man. I told him there's something you should know about, that I think should be brought to your attention. Your son doesn't make good on his debts. And, you know, his old man and I had a very pleasant conversation. He was grateful to me for telling him and said he would take care of the matter himself. Then he asked me if I'd send him one of my books, and would I autograph it."

Nelson got up to fix another pitcher of martinis while I called up a woman I knew named Kathy to invite her over. I'd known Kathy from Iowa City, and now we were all in Chicago, and I thought it would be wonderful if she could join us. Kathy took a cab over, and the night went on. She and I danced, she and Thede danced, Thede and I danced. "Because I am mad about women, I am mad about the hills," Thede declaimed, gulping down a swig from Nelson's pitcher. Tearing off his shirt, rivulets of sweat pouring down his massive hirsute chest, Thede, Yeatsian dancing bear, finally wound up with the floor to himself.

As for Nelson, I don't recall that he danced at all that night. Mostly I remember him sitting back in his easy chair, viewing the proceedings, drink in hand, with his remote control push-button channel changer nearby. As for me, I was having a grand time, a splendid time-when again it happened. All those martinis and nothing to eat-again I was in trouble. The night ended for me, ignominiously, on Nelson's couch, with Thede giving out shortly thereafter. In the meantime Nelson graciously called a cab for Kathy.

I woke up in the morning feeling horrible. Nelson fixed bacon and eggs for the three of us, but I couldn't keep any of it down. I couldn't keep anything down. "Burns, are you ready for some more bacon?" Nelson called from the kitchen as I raced to the john. He offered me hot cereal, but 
whatever I tried to eat, my stomach rejected. But I had to get something down. There was no choice, l'd have to go to the Cook County Hospital and be fed intravenously. Nelson saw us off on the bus, Thede accompanying me the rest of the way. When I got to the emergency ward I was placed on a cot until somebody could attend to me. Finally the combination of a Vitamin B shot and a milkshake set me straight. The night before we had all talked about getting together again the following evening. But somehow the plans got changed. Nelson invited Kathy to see a play with him and Studs Terkel. Thede and I went to a Howard Street movie. We ate popcorn, with nips from a pint of Old Crow in a brown paper bag.

In the spring of 1970 , still imbued with the belief that one day I would write something that would make Nelson Algren sit up and take notice, I boarded a Greyhound Bus bound for New York. Midafternoon, the bus pulled into Chicago and stopped at the Greyhound Station on Randolph and Clark, the driver announcing there'd be a two-hour layover. Leaving my suitcase in a locker, I walked down Clark Street to Division. The bars and strip joints were gone, replaced by parking lots and used car agencies. I went into a phone booth and asked information for Nelson Algren's phone number. It was unlisted. On Division Street, I hopped a bus to Damen Avenue, then walked the two or three blocks to Nelson's old address, 1959 Evergreen. The name Algren was still printed on the big mailbox inside the door. I walked up the winding stairway. There was a "Do Not Disturb" sign on one of the three doors in a small cramped hallway. I could hear music being played on a radio or record player from behind the door with the sign on it. Should I knock on it or not? I knocked and waited. No answer. Maybe he was sleeping - maybe he had somebody in bed with him. Maybe he was in the john, in the shower. I knocked again. I heard the music being turned down. Then the door opened, and there he stood, in a raggedy undershirt and bermudas, pot belly, thin white hairless legs, a wispy white thatch of hair on his head.

"Why, hello, Burns, come in," he said, as though I had just seen him the day before. "Sit down. Let me get you a drink." He went into the kitchen. I looked around the apartment: the walls lined with books, the big green plant by the window, the TV in front of the window, the photographs of Hemingway and Dostoievski and Brendan Behen, one of Joan Baez, photographs of Nelson himself with friends, a framed poolroom 
poem of his, the fading photograph of a 1927 basketball team - Nelson Abraham, the second one from the right. And above his easy chair - there was Pablo's Quaker Oats poster. A turn-of-the-century poster of a little girl with a St. Bernard. Pablo and the Cincinnati Kid had found it rummaging through an abandoned Iowa farmhouse. He'd had the poster hanging in the farmhouse we shared, and Nelson had been taken with it the first time he saw it. "Would you like to have it? It's yours," Pablo had told him. The Cincinnati Kid, though, objected; the poster was half his, and he wanted ten bucks for it. Nelson gave him the ten, but that might have been why he didn't give him a better reference when he applied for the job on the Fairbanks police force.

I looked at all the books on the shelves, the framed pictures and photographs - all the collected memorabilia. Longing so to have such a place for myself. A place to leave from, and come back to, that would always be there. A place where I could put $m y$ books on shelves, instead of having them scattered all across the country, boxed in closets, basements, and garages, stored with friends and strangers.

Nelson returned with a bowl of ice, glasses, and a pitcher of martinis, and we started talking about the Thursday night poker games in Iowa City. And it was as though we had just played in one the night before. We talked about Gilroy and Lepp, and Thede and Pablo, John the Barber, Micky Hagen, and the Cincinnati Kid. Then he wanted to know whatever happened to that lovely blonde anthropologist, the woman who was going to introduce him to Claude Levi-Strauss - "she was attracted to me, I could tell." He talked about having taken part in a recent Writers' Conference. A lot of frustrated and neurotic women were there, and one of them had pursued him back to Chicago. She'd stayed with him for a week or so until her "craziness started coming out" and he had to make her leave.

He told me about the woman who had sought him out for a magazine interview. She was from out of town, and after a pleasant evening together he had offered to put her up for the night. When she accepted, he dragged out a mattress and some sheets and blankets. Then he strung up a blanket across his living room so she would have some privacy. Saying goodnight, she stepped behind the blanket. As he was getting ready for bed he noticed that she still had the light on. He drew back a corner of the blanket and peered within. She was under the covers reading a book. 
"Yes?" he had asked.

"No," she had replied. "No!" he said, cackling as he shuffled out to the kitchen for more ice. He asked if I'd like to go out for dinner, or did I have to get back on my bus. No, I could always catch a later one. Good, he said. First, though, since it was Monday night we had to watch "Laugh In."

Afterwards, he said there was this restaurant we could go to, but that I would need a sport coat to get in. He brought out one of his and I tried it on. No, he didn't think that one suited me. He brought out another and I tried it on. I looked at myself in the mirror. It reached down almost to my knees. The shoulders were too big and the sleeves too long. "Fine, Burns, it looks good on you. Why don't you keep it."

"Nelson, I couldn't do that - "

"No, no, it's yours. I got others."

I looked at myself again. It wasn't exactly what I would wear to church or a wedding. But now if I was about to go on a trip to Las Vegas-especially if I was thinking to apply for a job as a shill-it would be the very thing. So I took it, and I still have it somewhere. Though I haven't worn it since the last time I was in Las Vegas.

During dinner he asked me what I was up to. I told him that a woman named Jennifer and I had been living on a ranch in California, in Marin County, on Tomales Bay. I told him that she was now in New York and that we planned to spend the summer in Vermont, then go back to Tomales Bay. He asked if it was anywhere near Stinson Beach, and I said it was just up the coast. He said he had been to Stinson Beach, and that he would like to live in a place like that. He wanted to live somewhere near water. He talked about San Francisco. Of all American cities, it was the one he'd most like to live in. He said he was feeling pretty isolated in Chicago, he'd made too many enemies there. He asked me what my friend Jennifer did, and I told him she was a film editor. He mentioned a story of his that had just been published in Playboy. It was a racetrack story and some people had approached him about making a movie of it. He said he thought it would make a good one, but that he didn't think these people would ever do anything with it. They didn't get the point of the story, and they wanted to make too many changes in it.

"They think 'No, this won't work, it's too grotesque, this dwarf and this big woman being matched-up.' But the guy ain't a dwarf, he just happens to be a little guy, a jockey, and she's a big woman, that's all. She 
brings a horse down to its knees by hitting it in the belly, but there's a trick to that. It's just a matter of being in the business, knowing horses. She's a big woman, but she ain't a grotesque."

We talked about Hollywood movies. He liked the early John Huston ones, movies like The Maltese Falcon and The Treasure of the Sierra Madre, and The Asphalt Jungle. But he thought Huston, what with living in his Irish castle and riding to the hounds, had ceased to care about making those kinds of movies. It happened to them all, they ceased to care.

I brought up something I had never mentioned before, the night I first met him, twelve years before, here in Chicago. I asked him if he remembered getting the letter of introduction from Karl Shapiro.

"Yeah, yeah, I remember the night. It was a wet rainy one. We had a couple of drinks. I don't remember where I took you, but we had something to eat. Then I got rid of you. To tell you the truth, I didn't know what you wanted, what you were after."

I told him that the night had been imprinted on me. For life. I had wanted to have 'literary' conversations and he talked about Charlie Starkweather and prizefights. I had wanted to 'know' Chicago and he suggested I get a job on the police force. Years later, in Iowa City, I told John Clellon Holmes about that night and he made me feel better by saying he'd had a similar experience the first time he met Nelson in New York. He too had been nervous, and Nelson had spent the evening putting him on, trying to introduce him to movie stars. I started to tell Nelson about that.

"Oh, no, he got it all wrong about that night," Nelson broke in. "I really wanted to have John meet these people." He went on to say how he had always been envious of what some performers could do - the way in which somebody like Geraldine Page could reach people, communicate from a stage. Or Rod Steiger, or Brando. "Yeah, yeah, I ran two blocks from where we were having a drink. I heard Geraldine Page was in this place. Then I found myself in a revolving door with Tony Curtis. I couldn't believe it, they were all over the place. So I ran all the way back to tell John. I wanted him to know I knew these people. Then I look where John is, and in the next booth, there's Shelley Winters, and she's with this guy, a smalltime director I know. So then I'm leaning back over the booth-" Here, Nelson leaned back over the booth to demonstrate: "-Get Shelley Winters over and introduce her to John Holmes," he cried in a loud mock-whisper. The elderly couple in the next booth stared at 
him, not knowing what to make of this. People at nearby tables looked our way. Oblivious to them, Nelson went on, "Yeah, yeah, and John, he's just sitting there, he ain't impressed, it doesn't mean anything to him."

We left the restaurant and Nelson hailed down a cab. On the way to Old Town, he and the cabbie talked about the White Sox. The cabbie turned off the meter until Nelson decided where he wanted to go. We stopped at a bar, then another - and now everything gets blurry and confused. I remember sitting in a bar and he's talking about how he would have liked to have known Stephen Crane and I'm talking about remembering when I was a kid and regretting I'd been born years too late to meet Jack London.

Walking through the brightly lit streets of Old Town, I ran into an old schoolmate from my hometown. I introduced him to Nelson, I told him this is Nelson Algren. They shook hands, and the three of us spoke briefly. Then we parted ways. And clearly the name hadn't meant anything to my old schoolmate. Nobody in Columbus, Nebraska knew who Nelson Algren was.

The next thing, Nelson was having words with a guy, heated words. I thought there was going to be a fight, but then the guy was walking away from us, Nelson shouting angrily after him. Then another cab. Nelson started to give the cabbie directions on how to reach his address, but the cabbie cut him short - he didn't need anybody telling him how to find his way around. The cab ride went on and on. I fell asleep. When I woke up, the cabbie was admitting to being lost and Nelson was trying to give him directions.

Back at his apartment, Nelson gave me an alarm clock and I lurched off to bed on his sleeping porch. My bus was leaving at seven in the morning, somehow I set the alarm for six.

Four-thirty, I woke up with a huge thirst and a splitting headache. I stumbled into the kitchen. A container of orange juice was on the table, the table set for two. I reached for the orange juice and gulped it down-I couldn't drink enough of it. Oh, dear God, how good it did taste-but then-Oh no! - not again! I dashed into the john, turned on the faucets, flushed the toilet. I didn't want him hearing me-I couldn't have that. I mean what was he going to think? Every time I saw him this happened? I came out of the john and there he was, padding about in his bathrobe. 
"Good morning, Burns, how are you? Ready for some breakfast?" He said he'd been up since three-thirty. He only slept a few hours a night, then napped in the afternoon. I told him I generally woke up pretty early too, and this time pretty thirsty. He said that was why he fixed the juice, and added that there was also Coke and lemonade in the refrigerator. While he fixed breakfast I felt another wave of nausea coming on. Oh Jesus! I fixed myself a Coke with ice cubes, maybe that would help. But it didn't. I went back to the john and turned the faucets on-maybe he'd think I was washing up. I came back out. He told me to sit down. Coffee was ready, the ham and eggs in just a few minutes. I looked at him wondering how he did it. He seemed to feel fine, and began talking about the two weeks he had been in Japan. He had gone to sweatbaths, where a masseuse might be topless or wearing a bikini. But sex didn't necessarily go with the massage. He'd had this one girl working him over, giving him this terrific massage, her right leg braced against him. He ventured a tentative reach at her leg, and she promptly said "No!" Then she changed positions so that her left leg was braced against him, and he thought, "Well, maybe I tried for the wrong leg. So I reached for the other one." Whereupon she pushed his head down into "a sort of declavity on the table" and held him neck down while continuing with the massage. "And, Burns, those girls are very strong-armed," he said, arching his brow. "They know what they're doing. There's no nonsense."

I tried some coffee, then the ham and eggs. Maybe that was what I needed. Something solid. But no - that wasn't helping either. Trying to be casual about it, I made for the john again. And again-with just enough time to get the faucets running. Maybe this time he'd think I was brushing my teeth. I doused my face with cold water. I came back out. Now he was talking about the Japanese version of $A$ Streetcar Named Desire that he had seen, and how the Japanese sense of decorum and restraint had affected the production.

". . . Now the way it's done here, when Stanley Kowalski is told to clean off the table, he takes the tablecloth and flings everything off. Then he says, 'There - the table's cleared.' But in the Japanese version, the guy simply picks up a spoon and raps it on the table. 'Table cleared,' he says."

I drank some lemonade, wondering if he suspected anything-if he knew. At all costs I couldn't let him know what distress I was in. I had to hold out - at least until I left his apartment. Now he was talking about his 
times in Vietnam. He had stayed in this hotel, where he kept having to move from one room to another. In one room he had a pipe that was leaking water. He asked the maid to take care of it. She mopped up the floor. He pointed out that the pipe still leaked. She tied a rag around it. The pipe still leaked, so he got himself another room. When he went to bed he discovered that the light above his bed wouldn't work. The cord was burned out. He went downstairs and asked if somebody could fix it. A tall gangling fourteen-year-old boy came to the room. Showing him the burned-out cord, Nelson tried to explain that it should be taped up, that the hotel could catch on fire. Then he turned on the light switch to demonstrate that the light wouldn't go on. Nodding, the boy unscrewed the bulb from the socket. "Bulb no good," he said, shaking the bulb in Nelson's face.

"Yes, yes, I see the bulb. But will you fix this?" Nelson said, shaking at the boy the burned-out cord. But the boy had spotted some bananas on Nelson's bed. He asked if he could have one. "Yeah, yeah, I said he could have one. So now he's sitting on my bed eating my bananas, and he's forgotten all about the light. So I gotta move to another room. And I never did see the rest of my bananas."

Bananas-I didn't even want to think about bananas, nor had the lemonade helped. I made for the john again. Again turned on the faucets. Maybe this time he'd think I was shaving. Oh God-give me the strength! I didn't want to make another trip to the Cook County Hospital. I doused my face with more cold water, and came back out.

Nelson walked me to the corner of Milwaukee Avenue where I caught a bus to the Greyhound Station. I thanked him for the evening, for breakfast and the sport coat. It was a lovely spring morning. A bright blue sky, birds chirping in the trees. Everything was so clean and fresh, the beginning of a new day. And I just managed to make it to the station.

The last time I saw him was that fall, three months later. Jennifer and I had spent our summer in Vermont, and we were on our way back to California. Nearing Chicago, we stopped at a filling station and I called him. $\mathrm{He}$ said for us to come over. Some young kids from France had just showed up, the children of some of his old Paris friends, and he didn't know what to do with them. Maybe we could help out. We drove to his apartment and met him and the four or five young Parisians. They were touring the United States and had given themselves a day in Chicago. Nel- 
son had been painting the floor of his apartment when they arrived, and we all stood bunched uncomfortably around his refrigerator, the one place where the floor was unpainted. Nelson still hadn't made up his mind what to do. Finally he decided to take us to the South Side. We rode the El. I don't remember where we got off; I only remember that we were all standing on a street corner waiting for a bus when we noticed two young black men watching us. Both wore berets and para-military-looking outfits, and neither of them looked friendly. Nelson went over to talk to them, then drew me aside. "You know, I think maybe this was a bad idea coming here. Those guys, they're Blackstone Rangers. This is their territory, and things have been kind of tense here lately. Yeah, I think maybe we should go to the Brookfield Zoo."

We got back on the El, then rode buses, transferring from one to another, Nelson herding everybody on and off, purchasing tickets, seeing that everybody was accounted for, like a den master with his troop of scouts. The afternoon was spent at the zoo, Nelson now playing tour conductor. We took pictures and looked at the animals. Sitting in the bleachers of the dolphin tank, we watched the dolphins erupt from the water, landing with such exuberant splats it was as though they were trying to drench everybody in the audience. We ate hot dogs and drank soda pop, Nelson refusing to let anybody pay for anything. Nor would he that evening when he took us all to a Chinese restaurant for dinner.

Afterwards we returned to his apartment. Jennifer and I were driving on that night; but before leaving, I asked Nelson if anything was happening with the people who had wanted to make a movie of his racetrack story. He said nothing had come of it. I told him I'd been in touch with a filmmaker friend in San Francisco about trying to make a movie of it, and I asked him if he'd like for me to have my friend contact him. Yeah, if your friend was at all serious about it, he said. I told him that my friend didn't have any money, nor did I; nonetheless we'd work on it on speculation, or on "spec," as they say. Then I asked him if he'd be interested in working on a script of the story on that same basis. Which was when I made my second mistake with him.

"No, I wouldn't be," he said. "There's a way to do those things, and that's not the way." He was visibly stung that I had approached him with such a proposition. And I wince now, years later, remembering. That I could have been that insensitive. He had been conned and hustled already 
by Hollywood. He loved the movies and was in awe of movie stars, but I think he felt that the people who made movies were all Otto Premingers. Certainly that had been his experience. He had sued Otto Preminger, trying to stop him from turning his story of Frankie Machine into what he termed a "fictionalized biography of Frank Sinatra." And had lost the suit, along with the house he owned at the time in lawyers' fees. Asking him to write a script for a movie on "spec" - to him that was an unforgivable kind of hustle.

Nelson brought out a bottle and glasses, and the subject was dropped. We had a parting drink, all of us once more bunched together around his refrigerator. He talked about still wanting to come to San Francisco, and Jennifer and I invited him to come out and stay with us. Then we gave him Paul Newman's credit card number so that he could call and let us know when to expect him. That was the year Paul Newman had a credit card number on which he could make an unlimited number of calls. But then he got mad at the telephone company and made it a point to give out his credit card number to people all over the country. Or at least so the story went. After we got back to California, Nelson called and was pleased to find that the number really did work. He'd told the operator that this was on Paul Newman, and she'd put the call right through. Ripping off the telephone company, that was a different kind of hustle, that was a legitimate one. When he called, we again invited him to come out and stay with us. We had a guest room with a view looking down on Tomales Bay. Jennifer had put up new curtains, especially for him. He said he'd like to come out, but he never did.

The last time I talked to him was in the summer of 1974. I was traveling across the country on a Greyhound Bus. Since I had last seen him, I had gotten involved with a San Francisco-based film collective. The collective was made up of radicals and political activists, and Nelson Algren was one of their heroes. They wanted to make a documentary about him, and asked me if I would approach him about it. I tried to call him, but of course by now he had a new unlisted number. I called up Studs Terkel to get his number, and told him what the collective had in mind. He thought a documentary on Nelson would make a wonderful film, but he said it would be important to catch him at the right time, when he felt relaxed and comfortable. Nor did he think the people should try to work from a 
tightly written script. Better just to put the camera on Nelson and let him tell his stories.

A few days later, I called Nelson from where I was staying with a friend in Houston, Texas. When he answered the phone, I told him who I was, and he said something garbled that I didn't understand. I repeated myself.

"Why, hello, Burns. You know, at first I thought you were Rip Torn. Yeah, I was expecting a call from him. So how are you?"

I told him I was planning to come through Chicago, and asked if he had a night free. He suggested the following Tuesday and said to call when I got to town. After I'd hung up, it occurred to me that I should have said something about the purpose of my visit. I wrote him about the people in the collective wanting to do a documentary on him. Knowing how such projects go, it might not come to anything; but if nothing else, I said, they would spring for a free dinner. Which was where I made my third mistake with him. I no longer tried to tell him how to play poker, but in this area I still had to learn. "A free dinner." Otto Preminger would have done better than that. Two days after I wrote him I got a letter back:

"All literary inquiries are directed to my agent. I'll be out of town next week. Best wishes, Nelson A."

The bitterness that was there. I never knew just how deep it went. Maybe I had to acquire some bitterness of my own before I could really understand his. For him, it took the form of feeling that it would be a kind of selling out to try to write another "big book" like The Man with the Golden Arm. He would be selling himself out, as he saw it. Because writing that "big book" no longer mattered that much. It wasn't wanted that much, wasn't needed that much. Not enough, anyway, to justify making the commitment he felt would be required to write it. In Iowa City, he had referred to himself as a "journalist." He was most insistent about that. $\mathrm{He}$ was not a "writer," he was a "journalist."

A student once asked him what advice he would give to someone wanting to be a writer. "Go to Vietnam, or South America," was his reply. He could just as well have said, "Go to Kansas," as Truman Capote had, or "down a wild river in Georgia," as James Dickey had. It wouldn't have changed what he meant. He believed that to be a writer you put yourself on the line. You held nothing back. You went all out. And - out of bitterness and wounded pride-he would no longer do that. 
Yet he couldn't help himself. He still sought out the stories. In the early 60 s, at an age when most men are looking ahead to retirement or bouncing grandchildren on their knees, he shipped out on a freighter to Asian ports. Out of which came his book, Notes from a Sea Diary, subtitled Hemingway All the Way. Later, following his own advice, he went to Vietnam. Not to hobnob with the U.S. military brass, or to dine out with Elsworth Bunker, but to live with the Vietnamese.

I never thought he would leave Chicago, the city that had so divided his heart. That is, leave the city and not come back. But finally he did. In 1974, he moved to Patterson, New Jersey to write a magazine piece about the black prizefighter Ruben "Hurricane" Carter, convicted of a triple homicide in a barroom holdup. The years went by, and I didn't hear very much about him.

During those same years I moved from San Francisco to Denver and gave up writing my rejects. I wrote melodramas and musical comedies that were performed in a dinner theater. The shows drew sell-out crowds, got good reviews, and there was even talk of one being taken to Broadway. I was a success. I lived in a condominium, and for the first time in my life owned a car. My father was proud of me. He had always felt that when people went to the theater they didn't want to be told how grim and awful life was; they wanted to forget their problems, not be reminded of them. Now I was doing what he had been wanting me to do for years. I was in show business, writing "family entertainments." Having at last justified my life to my father, that should have been enough. But it wasn't. Because I knew I wasn't writing anything that would make him sit up and take notice.

So that there was no longer any excuse at all for me to call up some Famous Syndicated Chicago Columnist or Studs Terkel to get Nelson Algren's current unlisted telephone number. I had no reason whatsoever to go tracking him down and knock at his door. With or without a letter of introduction. Unless, of course, I was that desperate to find a poker game.

In the winter of 1981, I learned that he was living in Sag Harbor, New York, an old fishing town on the tip of Long Island. Jennifer, the woman I had been with when I last saw him, had gone there to visit her sister and husband; and while she was in Sag Harbor, she was told that Nelson Algren now lived there. He had been very kind and gracious to her when she 
met him, and had given her an autographed copy of The Neon Wilderness. But that had all been some years before, and she hadn't tried to see him. I wish that she had.

When my friend called to tell me that Nelson Algren had died, I was reading an article about Charles Dickens. In H. E. F. Donohue's published conversations with him, Nelson had mentioned Charles Dickens in talking about how a writer seeks a certain kind of love:

... anybody can get married and have children. He (the writer) wants to be the one who does it differently. Anybody just by falling in love and having somebody fall in love with him can achieve that, but not many people can get love the way Dickens had, where people, an ordinary housewife, would follow him down the street and thank him for the people that he had given her.

"Burns, I'll tell you what your problem is. Your problem is that you take too long to get to the point."

So what is the point?

The point is, Nelson, you were a terrible poker player, and along with the rest of the sharks I won from you your money. But what I wanted much more than your money was to win from you your love. And the only way I could do that was by writing something that mattered. So I write this now. Only of course now is too late.

Algren's Body Is Unclaimed was the headline that appeared in the San Francisco Chronicle two days after his death.

Funeral arrangements of novelist Nelson Algren, an author who wrote lovingly of life's losers, were uncertain yesterday because nobody had claimed his body at the Suffolk County morgue.

The article went on to say that the Sag Harbor police "knew of no immediate survivors." The unclaimed body. Surely someone came forward to claim it. But it wasn't for me to be that one. I had no claim to make upon the body. But I do make my claim upon him. Who so deeply touched my life. For better and for worse. For keeps and a single day. Yet 
I wonder. How much did I really know him? How much did anybody? The body unclaimed. To the very end he was his own "lonesome monster." And just now I feel I am one too.

"And I felt as though I had just lost a father." Fathers. I have been blessed with two of them. And I have been cursed. For all the years I've spent seeking out the love and approval of each, knowing always that if I succeeded with the one, I would be failing with the other. Fathers. In a certain way, this has been about both of them. And who knows? Perhaps in writing this, that ongoing conflict may at last be resolved; and henceforth, having written for them, I can learn to write for myself.

Sunday, May 10th, 1981. I didn't know how to get in touch with Gilroy or Lepp. John the Barber was probably still in jail. Last heard, the Cincinnati Kid was still in Anchorage dealing a house game, and Micky Hagen was still somewhere missing in Fresno. But Pablo and Thede were in town. I called them, and the following night we held the First Annual Nelson Algren Memorial Poker Game.

The game began as it always began; cards fell as they always fell.

A wind came up like wind does. Rain began like always. Juke played what it always plays.

We said the things we always say. Barflies drank what they always drink.

All on a moon of the arfy darfy.

Yet all of it was different, and none of it the same.

Because now he was gone. 